\title{
NON-AGENDA
}

With the view of causing an increase to take place in the mass of national wealth, or with a view to increase of the means either of subsistence or enjoyment, without some special reason, the general rule is, that nothing ought to be done or attempted by government. The motto, or watchword of government, on these occasions, ought to be - Be quiet...Whatever measures, therefore, cannot be justified as exceptions to that rule, may be considered as non-agenda on the part of government.

- Jeremy Bentham (c.1801)

\section{Taxi Industry Reform: Should There Be Compensation?}

\section{Alan Johnston}

$\mathrm{A}$ cross Australia, the taxi and hire car industries have long operated within a web of regulations governing price, quantity and quality. Throughout much of this period, there have been concerns about the consequences of regulations which mandate fares and numbers of taxis and enforce market segmentation through restricting competition from close substitutes (eg hire cars). More recently, an Industry Commission (IC, 1994) report on urban transport, that recommended deregulation of taxi fares and entry restrictions, stimulated renewed interest in taxi regulation.

The IC report built on a tradition of policy analysts seeking to reveal, to decision-makers and the community, the costs of taxi regulations which have been premised on often well-meaning grounds such as public safety and ensuring fair prices and adequate quality for consumers. Today, the focus of the debate has shifted. Increasingly governments are being required to grapple with difficult questions about how much reform is warranted (the end point) and how it can be achieved (the reform path).

A critical event in the transformation of concerns about taxi regulation into more reform-oriented action occurred in April 1995 when the Commonwealth and all State and Territory governments signed off on the National Competition Policy (NCP) agreements. As part of NCP, all jurisdictions agreed to review their regulations with an eye to the guiding principle that legislation should not restrict competition unless it can be demonstrated that the benefits of the restriction to the

Alan Johnston is a Research Manager with the Productivity Commission. The views expressed in the article do not necessarily reflect the views of the Productivity Commission. 
community outweigh the costs, and the objectives of the legislation can only be achieved by restricting competition (NCC, 1997).

When the States and Territories trawled through their statute books, regulations governing the taxi industry quickly achieved 'prime suspect' status warranting close scrutiny. As a result, across each of the jurisdictions, reviews are either in progress or have been forwarded to government for consideration. In one jurisdiction - the Northern Territory - the process has been completed.

\section{The Reviews}

The Northern Territory (NT) Government's taxi reform program commenced in January 1999. It involved the deregulation of entry into all sectors of the industry (taxis, hire cars and minibuses). Taxi licences were cancelled and compensation was paid to licence holders. Ministerial control of taxi fares (apparently for an interim period) was retained.

In Western Australia (WA), the final report of the taxi industry review (WADT, 1999) recommended a gradual easing of entry restrictions, compensation for existing licence holders and the retention of regulated fares. In response, the Western Australian Government has established another review group to monitor developments in the taxi industry over the next two years (Criddle, 1999).

In New South Wales (NSW), the Independent Pricing and Regulatory Tribunal (IPART, 1999) recommended progressive liberalisation of entry restrictions in Sydney by increasing licences by five per cent per annum for the next five years and that maximum fare regulation continue. It also recommended that entry restrictions for hire cars be removed. IPART called for a further review after five years. A government decision is pending.

The Tasmanian Taxi Industry Act 1995 already provides for liberalisation of entry restrictions. Additional licences are made available annually in each area by a call for tenders. The number of new licences is either five per cent of the number of licences in an area, or one (whichever is the greater). The Tasmanian taxi industry review (TTIRG, 1999) did not recommend significant changes to the Act apart from the replacement of set fares with regulated maximum fares. A government decision is pending.

Confidential review reports are also with the South Australian, Victorian and Queensland governments. The Australian Capital Territory (ACT) taxi industry review has not yet been completed.

The general tenor of these reviews is that some reform is warranted. However, the potential winners are diffuse and not well organised unlike the potential losers who can be expected to campaign for retention of the status quo. While governments may find it easier to opt for policy inaction, NCP requires that any failure to act on review recommendations must be supported by a demonstrable 'public interest' rationale. Jurisdictions that do not comply with this requirement put at risk some of their competition policy payments. 


\section{Impacts of Taxi Regulation}

In light of the available evidence, a 'public interest' case for retention of the status quo in most jurisdictions would be difficult to sustain (Table 1). Most reviews have identified entry restrictions as a pervasive form of regulation - particularly the capitalisation into taxi licences of the economic rents flowing from restraints on competition.

Table 1: Licence Values, Lease Costs, Taxi Densities and Licence Ownership, by State, 1998

\begin{tabular}{|c|c|c|c|c|}
\hline Jurisdiction & $\begin{array}{c}\text { Licence } \\
\text { value (\$) }\end{array}$ & $\begin{array}{l}\text { Annual } \\
\text { lease } \\
\text { cost (\$) }\end{array}$ & $\begin{array}{l}\text { Taxis per } \\
\text { l0000 } \\
\text { people }(\%)^{a}\end{array}$ & $\begin{array}{l}\text { Licence owning } \\
\text { investors (\%) }\end{array}$ \\
\hline $\begin{array}{l}\text { New South } \\
\text { Wales }\end{array}$ & 260,000 & 18,700 & 8.6 & $\begin{array}{l}50 \% \text { of licences are } \\
\text { leased to operators } \\
\text { of taxi businesses. }\end{array}$ \\
\hline Victoria & 265,000 & na & 8.5 & na \\
\hline Queensland & 267,000 & na & 7.9 & na \\
\hline $\begin{array}{l}\text { South } \\
\text { Australia }\end{array}$ & 158,000 & na & 7.4 & na \\
\hline $\begin{array}{l}\text { Western } \\
\text { Australia }\end{array}$ & 210,000 & 19,760 & 7.2 & $\begin{array}{l}60 \% \text { of licences are } \\
\text { owned by absentee' } \\
\text { investors. }\end{array}$ \\
\hline Tasmania & 100,000 & na & 12.9 & $\begin{array}{l}\text { In Hobart, } 8 \text { owners } \\
\text { hold } 31 \% \\
\text { licences. }\end{array}$ \\
\hline ACT & 280,000 & 26,000 & 6.9 & $\begin{array}{l}\text { Not specified, but } \\
\text { leasing is common. }\end{array}$ \\
\hline $\begin{array}{l}\text { Northern } \\
\text { Territory }\end{array}$ & 230,000 & 26,000 & 6.9 & $\begin{array}{l}\text { Before deregulation, } \\
80 \% \text { of licences in } \\
\text { Darwin were held by } \\
\text { 'absentee' investors. }\end{array}$ \\
\hline
\end{tabular}

\footnotetext{
${ }^{a}$ Estimates are for 1995.
}

Sources: IPART (1999); ORG (1999); WADT (1999); TIRG (1999). 
By 1998 , regulation-induced scarcity meant that the cost of taxi licences exceeded $\$ 200,000$ in NSW, Victoria, Queensland, WA and the ACT. In parts of the NSW central coast, licence values as high as $\$ 350,000$ have been reported (IPART, 1999). In South Australia (SA), liberalisation of entry restrictions into the hire car industry has provided significant competition for the taxi industry and this is reflected in lower taxi licence values.

These prices have put ownership of taxi licences out of the reach of most taxi drivers. Half of Sydney's taxi licences are owned by investors with no further active involvement in the industry. The corresponding figure for WA is 60 per cent. Prior to deregulation in the NT, around 80 per cent of licences in the Darwin area were held by investors.

Given regulated fares, the high cost of entry into the industry has a major bearing on the returns that investors can achieve from leasing taxi licences. For example, the Productivity Commission (PC, 1999) estimates that the current income stream from leasing a Sydney taxi licence equates to the value of the licence at a discount rate of around seven per cent in perpetuity. This is only equivalent to the (risk-free) long term bond rate.

In 1998, the annual cost to lease a taxi licence was highest in the ACT at around $\$ 26,000$ per annum, the same as for the NT. Consistent with this, these two jurisdictions had the lowest taxi densities at around seven per 10000 people. (This stands in stark contrast to taxi densities in the deregulated New Zealand market - for example, Auckland has around 29 taxis per 10,000 people.) Lease rates in Sydney, which has similar licence values to the ACT but a higher taxi density, are much lower at around $\$ 18,700$. This implies a cost to users of Sydney taxis of around $\$ 75 \mathrm{~m}$ per annum (PC, 1999). In WA, increases in licence values have led regulators to mandate lease rates at $\$ 380$ per week $(\$ 19,760$ per annum). This imposes a cost on consumers of $\$ 20 \mathrm{~m}$. per annum or $\$ 3.00$ per average fare (WADT, 1999).

Lease costs are probably recouped through higher fares. Findlay and Round (1995:64) consider that, because the cost of entry is so high, it 'leads owners to press, through the regulatory system, for higher fares in order to provide a higher return on their investment in the plate'. Throughout Australia, mandated maximum fares have become the operative norm.

That said, it is important to posit what outcome might arise if regulators have somehow set the maximum fare at the level that would prevail in a free market. In this instance, the higher throughput per taxi enabled by the restricted number of licences would allow operators to absorb the high licence and lease costs impost. In this case, the loss of consumer surplus would be manifested through longer waiting times and non-availability of taxis, particularly at peak times.

Most analysts have concluded that the entry barriers lead to both higher (regulated) fares and longer waiting times. For instance, Gaunt and Black (1996:57) attempted to measure the transfers and deadweight losses associated with regulation of the Brisbane taxi industry. In 1993, taxi regulation had resulted in a Brisbane taxi licence having a value of $\$ 190,000$, reflecting 228 fewer cabs 
than would arise under a competitive regime and an increase in fares of $\$ 1.47$ for a standard $8 \mathrm{~km}$ trip. Gaunt and Black concluded:

The public or consumer interest has suffered an estimated $\$ 20.67$ million annual loss of wealth in 1993, while between $\$ 11$ million and $\$ 19.1$ million of this loss has been picked up by the politically powerful licence holder lobby and between $\$ 1.48$ million and $\$ 9.55$ million has been lost to society with no group directly benefiting [the deadweight loss].

These costs are borne most heavily by low-income households (Soon, 1999; IC, 1994). Moreover, the restrictions on competition reduce incentives for taxi operators to explore new ways of better providing services to meet users' needs. For example, the regulations work against the development of budget cabs to provide a lower cost service (eg non-air-conditioned budget 'shopping shuttle' services). Such quality-cost trade-offs are evident in less regulated markets such as in the United Kingdom, Sweden, New Zealand and many Asian markets.

Most of the reviews have expressed little difficulty with existing 'quality' based regulation. However, the PC (1999) considered that regulations mandating vehicle types and age are overly prescriptive for meeting safety and quality objectives.

Overall, regulation of the taxi industry leads to reduced supply and consumption of taxi services, higher prices, a stifling of innovation, forced transfers from consumers and significant deadweight losses.

\section{Sequencing of Reforms}

The review material in the public domain point to a need for less restricted access into the industry. One option would be to adopt the New Zealand approach of simultaneous deregulation of entry and fares. However, given that the industry and consumers have, over many decades, become accustomed to a tightly regulated environment, some reviews have proposed that reform should be sequenced by concentrating, initially, on the elimination of entry restrictions before tackling deregulation of fares.

In terms of such sequencing of reform, current thinking is essentially the obverse of that advocated by the Industry Commission (1994). The IC recommended immediate deregulation of fares in association with progressive liberalisation of entry. This approach was criticised by Gaunt and Black (1994) who consider that, in taxi markets subject to strong growth and/or with low taxi densities, the combination of fare deregulation and only a progressive easing of entry restrictions could lead to fare increases and even short term increases in licence values.

Liberalisation of entry restrictions should be the first port of call for any progressive reform of the taxi industry. Indeed, the Productivity Commission (the 
successor to the IC) considers that there is a strong case for retention of maximum fares as a transitional measure if entry restrictions are progressively removed.

In the long term, the best approach for fares may differ according to the characteristics of particular taxi markets. At airports, for example, allowing consumers to 'shop' up and down taxi ranks for their preferred cost-quality combination could create congestion problems. In markets, where phone bookings dominate and hence, search costs are low, full deregulation of fares could allow consumers to negotiate prices in an unpressured environment. Conversely, if the proportion of rank and hail trade is high, fare competition through the mandatory posting of prices on taxis, similar to the system which operates in New Zealand, may be appropriate. Posted prices can overcome problems for consumers uncomfortable with haggling and reduce the scope for price gouging arising from the market power a taxi may have because of potentially high costs in locating another taxi (particularly during inclement weather). It is also likely that with the removal of entry restrictions, a regulated maximum fare would no longer be binding and discounting could emerge.

Issues revolving around the sequencing of progressive deregulation of the taxi industry pale in comparison to the most difficult issue occupying the minds of many in State and Territory governments - the vexed question of compensation.

\section{The Case for Compensation}

As the value of taxi licences is essentially the embodiment of scarcity created by the entry restrictions, their value would fall substantially - possibly close to zero - if entry restrictions were abolished. Reform therefore potentially imposes very large losses on a small group of individuals. This may be regarded as unfair.

To ameliorate such difficulties, economic reforms are often phased. This can cushion the extent of the adjustment shock and minimise transitional losses which may be magnified or endure longer in the absence of phasing. Phasing can also provide activities with the opportunity to make further use of sunk assets. However, unlike most physical assets, taxi licences tend to appreciate. The market value of licences reflects the present value of expected future excess profits from a continuing constrained competitive environment. Thus, the phased liberalisation of entry restrictions would have an immediate negative impact on licence values.

The only way in which a phased approach to freeing entry restrictions would not result in significant losses for existing licence holders would be if it occurred over an inordinately long period - for example, an announcement that a program of liberalising entry restrictions would commence in 20 years time. Clearly, such an approach would defer the achievement of the efficiency gains. Herein lies a key trade-off between transfers and efficiency.

Phasing means that the efficiency gains are delayed and are fully achieved only when the entry restrictions are completely liberalised. Moreover, transfers from taxi users to licence holders continue over this period. Relative to a phased 
approach, compensation brings forward the achievement of efficiency gains, but increases the size of transfers from taxi users to licence holders.

The political response to this situation is mixed. In New Zealand, full deregulation was achieved without any compensation (albeit that licence values, at around AUD $\$ 20,000$, were significantly lower than those prevailing in Australian markets). On the other hand, the NT government provided a compensation package based on the full market value of licences. The Western Australian review proposed compensation of a similar magnitude, but accompanied only by progressive liberalisation of entry restrictions. The IPART report on the NSW taxi industry recommended a phased increase in taxi licences and removal of entry barriers into the hire car industry where licences sold for over $\$ 140,000$ in 1998 . If implemented, these reforms would have an immediate negative impact on licence values, as has occurred in SA. Yet, IPART is silent on the question of compensation.

Key considerations that bear on whether or not to compensate relate to the nature of the property right attached to taxi licences, perceptions of fairness, and pragmatic considerations such as the ability to progress reforms in the absence of compensation.

\section{The question of property rights}

A taxi licence is an asset that has been created by government policy but without an explicit guarantee that it would continue in perpetuity. For example, all governments have periodically increased the number of taxi licences which has affected their values. However, while most taxi licences have been freely allocated, governments have allowed them to be traded and some have recently captured the economic rent through licence auctions. These factors could be construed as governmental recognition of the status of licences as a property right. Indeed, had all licences been auctioned, a case for compensation would seem to be quite powerful.

Fundamental to this issue is whether a change in regulation goveming entry is an attack on the property right in the licence. For example, the Australian Constitution provides that landowners have a right to 'just compensation' should their land be compulsorily resumed, whereas other government actions which also affect land values, such as changes in zoning and land use regulations, typically do not attract compensation. Liberalisation of entry restrictions into the taxi industry, while diminishing the value of licences, would not involve a resumption of the property right - licences would continue to operate.

In terms of precedents, the responses by governments when they have created 'property rights' and subsequently eroded their value or removed them is mixed. For instance, when the NSW egg industry was deregulated, compensation for the loss of value of egg quota was paid to egg producers. On the other hand, many other activities in similar situations have not been compensated - for example, the loss of income for members of the legal profession when some governments removed their exclusive right to engage in conveyancing of property. 
In sum, the nature of the property right inherent in a taxi licence is at best equivocal.

\section{Fairness}

As liberalisation of taxi entry restrictions would impose large losses on some individuals, it may be regarded as inequitable or unfair thereby warranting some form of restitution. Perceptions of fairness vary markedly depending on a particular individual's values - for example, a reform which subjected some individuals to large uncompensated losses would be regarded by many as unfair, even if it redistributed income from wealthy households to a group of disadvantaged individuals. In this instance, equity and fairness would not be synonymous.

Forsyth (1999:235) observes that 'economists are uncomfortable with the notion of fairness or justice ... but it is not something they can ignore. Others in society do have concepts of what is and is not fair, and may expect fairness to be taken account of when decisions are made'. While one person's perception of fairness is no more valid than another's, economists have a role to play in informing decision-makers about the losers of reform and the extent of their losses.

For this purpose, it is important to note that the values which derive from barriers to entry in the taxi industry are appropriated by licence owners - that is, investors (who have little further involvement in the industry) and owner-drivers (licence owners who drive taxis). Lessee-drivers (drivers who lease the licences from owners) and casuals have no claim over the value of the licence. Thus, they would not experience a capital loss if licence values fell. On the contrary, they would face a significant reduction in lease costs of around $\$ 20,000$ per annum. Moreover, as an expansion in activity would follow the removal of entry restrictions, employment opportunities for drivers should increase. In this instance, equity is unlikely to be adversely affected because reform would not appear to have a particularly regressive distributional impact.

The proportion of licence-owning investors varies across taxi markets but is generally substantial (Table 1). It is valid therefore to ask whether investors, particularly those leasing many licences, should be expected to understand the risk associated with an asset based purely on government fiat, and have a stronger financial capacity to 'wear' losses. Argy (1999), for example, considers that the case for compensation is stronger when the change is an unexpected breach of long standing tradition and those who are hurt are relatively poor. Of course,

\footnotetext{
${ }^{1}$ Interested readers are directed to Posner (1992) for a general discussion of property rights; Epstein (1985) and Clegg (1995) on the extent to which regulatory actions that diminish the value of property constitute a compensable 'taking' in the United States; and Kenny and McNutt (1998) on legal reasoning from the United Kingdom which argues that a change to a taxi licence condition that reduces its value cannot be regarded as an attack on the property right in the licence.
} 
some owner-drivers may be people who have invested their severance pay 'nest egg' in a taxi licence.

It is also pertinent to consider the differential impact of deregulation upon new licence holders, who paid current market prices to enter the industry, and long term incumbents in the industry - many of whom received a freely allocated licence. Newcomers would unequivocally be worse off. For long term incumbents, it can be argued that, depending on their time of purchase and the price they paid (possibly zero), they could have paid off their initial investment and are only facing the loss of a potential capital gain. That said, the IC (1994) rejected this view on the basis that newcomers and long term incumbents lose the same amount.

Finally, the possibility of government policy changes is simply a feature associated with buying a licence in this sector. Failure to understand risk, whether sovereign or market related, does not constitute a case for compensation.

\section{Buying reform}

A pragmatic rationale for compensation may sometimes be based on judgements that community support for reform may need to be secured through the provision of compensation or other forms of assistance. For governments, this can mute adverse criticism from the losers thereby helping to progress politically unpalatable reforms.

However, this approach carries a degree of risk. It can encourage others facing losses to agitate for compensation, thereby stalling beneficial reforms or forcing the introduction of modifications which reduce the benefits. Moreover, rent-seeking behaviour, leading to excessive resources being diverted to lobbying, would be encouraged - an unproductive activity from a national perspective. The risks of this occurring can be seen in the context of many reforms where currently compensation is not a normal part of policy (eg introducing poker machine restrictions, removing cross subsidies which have advantaged some users of goods and services, and reductions in tariffs which devalue sunk assets such as textile plant and equipment).

Thus, the decision by governments on whether to compensate will be determined by value laden criteria on a range of matters such as perceptions of fairness, the possibility of reform not proceeding in the absence of compensation and the nature of the taxi industry in each jurisdiction.

On the basis that some governments may elect to provide compensation, it is useful to canvass how it could be delivered, who should receive it and factors determining the magnitude of payments.

\section{Delivering Compensation}

There are two major means of funding taxi industry compensation - from taxi users or taxpayers in general.

A beneficiary pays approach would involve compensation being paid by taxi users through mechanisms such as a levy on taxi journeys or an increase in taxi 
licence fees passed on to users through higher fares. The latter approach was adopted by the Northern Territory Government which provided up-front compensation that is to be recouped through taxi licence fees over nine years.

Delivered in this form, compensation represents an advance payment to licence holders of the capitalised value of the stream of transfers from consumers. Consumers continue paying these transfers up until the compensation package is fully funded, but, assuming the supply of taxis increased, some benefits (eg reduced queuing, more product innovation and consumer choice) commence immediately.

The extent and timing of price benefits for consumers is dependent upon the nature of the measures to recoup the cost of the compensation package. For example, if compensation is funded through licence fees, a fee set between zero and current market lease rates for taxi licences would be expected to deliver some early price benefits, but the full price benefits would not eventuate until the compensation was fully funded and the licence fee 'surcharge' removed. Conversely, a fee set higher than market lease rates would initially increase fares, but the transition to a deregulated price would be achieved more quickly. Of course, the higher the licence fee, the greater the barrier to entry.

Taxpayer-funded compensation spreads the costs over all taxpayers including those who may not use taxi services. If it was paid up-front, the efficiency gains and consumer price benefits would accrue immediately. However, governments would need to be mindful of the opportunity cost of revenue transferred to licence holders (ie money no longer available for other goods and services). Moreover, if revenue to fund the compensation program needs to be raised, the deadweight costs of taxation enter into the calculus. Currently, the States and Territories are reliant upon a range of relatively inefficient and, often regressive, taxes (Gabbitas and Eldridge, 1998).

Governments should ideally evaluate the relative efficiency of raising funds from a tax on users versus one on taxpayers in general.

\section{Setting a Ceiling on Compensation}

To the extent that licence costs embody more than their value in pure investment terms - that is, the security value of 'buying a job'(Swan, 1979) - and there is any goodwill component in the value of licences, then, compensation based on current market values would exceed the losses experienced by licence holders. Thus, any compensation package should be discounted by any goodwill and security value in the licence.

Compensation for all licence holders based on market value of licences, even if discounted by any goodwill and security value, would impose a large (initial, in the case of the beneficiary pays approach) call on the budget. The compensation package for the NT taxi industry cost around $\$ 27 \mathrm{~m}$. A similar approach would cost well over $\$ 1$ billion in Sydney alone.

Policymakers may opt for a combination of phasing and partial compensation in order to reduce the budgetary impact of reform. If compensation is to be paid 
in tandem with the phasing of reform, then the net present value to licence holders of that phasing should be discounted from any compensation package.

Other factors which could have a bearing on the level (and distribution) of compensation are considered below.

First, full compensation would provide the realisation of a windfall gain for the many long term incumbents - in particular, those who have benefited from the receipt of freely allocated licences. Consequently, compensation could be restricted to recent entrants who have not had sufficient time to amortise the cost of the licence. One approach would be to base compensation on the purchase price of licences indexed to the consumer price index (CPI). This would mean that recent licence holders would be compensated for the loss of the entire value of their purchase (ie the current market value). On the other hand, long term incumbents, having been compensated for their purchase price only, would face the loss of a potential capital gain (ie the current market value less the indexed purchase price). Those who received a freely allocated licence would not be compensated.

Second, the market value of licences reflects licence holders' 'speculative' assessments - based on past trends - about the net present value of expected increases in future earnings from a constrained regulatory environment. In this context, it may be considered that compensation based on market values would mean that those paying for compensation (ie taxi users or taxpayers) would have to bear the burden for future expected rents that may, or may not, have arisen akin to paying a winning bet before the race is run. Compensation could be capped at the net present value of the stream of income given by the current lease rate (thereby excluding any provision for capital appreciation).

Finally, some government social welfare payments (eg the age pension) are subject to an income and/or asset test to demonstrate the need for government support. A form of this approach could be applied to any compensation provided to licence holders. This would tend to direct compensation payments to individuals with relatively few assets and/or income sources rather than to 'professional investors'.

\section{Conclusion}

Reform of the taxi industry is long overdue. For too long, consumers have been taken for a ride. Governments throughout Australia have now been presented with the opportunity to use National Competition Policy as a 'whipping boy' for reform of the taxi industry.

If reform is to be sequenced, there is a case for concentrating, initially, on freeing up entry restrictions. Once a more competitive regime is in place, fare reductions should emerge even under a regulated maximum.

For consumers, the greatest benefits lie in immediate and uncompensated reform. However, this would impose large and disproportionate losses on a small group of individuals. Phasing the liberalisation of entry restrictions is unlikely to mitigate the losses that will be experienced by owners of taxi licences, unless the 
phasing is over an inordinately long period. Thus, compensation emerges as a key issue.

The decision on whether or not to compensate is inexorably tied up with perceptions of what constitutes fair treatment and also judgments about whether reform can be secured without restitution for the losers. Compensation has the attraction that the efficiency gains from reform are delivered earlier than would arise under phasing. The downside is that the quantum of transfers from consumers to licence holders will be larger than would arise under noncompensated and phased approaches, unless the basis for compensation payments is significantly less than current market values for taxi licences.

\section{References}

Argy, F. (1999), 'Distributional Effects of Structural Change: Some Policy Implications; pp. 39-91 in Productivity Commission, Structural Adjustment - Exploring the Policy Issues, Workshop Proceedings, AusInfo, Canberra, 21 May.

Clegg, R. (1995) 'Reclaiming the Text of the Takings Clause', South Carolina Law Review 46(4):531-578.

Criddle, the Hon. Murray, Western Australian Minister for Transport (1999), 'Special Review Group to Oversee Reform in the Taxi Industry', Media Statement, 26 November.

Epstein, R. (1985), Takings: Private Property and the Power of Eminent Domain, Harvard University Press, Cambridge, Massachusetts.

Findlay, C. and D. Round (1995), 'Reforming Australia's Taxi Markets', Agenda 2(1):6372.

Forsyth, P. (1999), 'Structural Change: Objectives, Evaluation and Incentives', pp. 233250 in Productivity Commission, Structural Adjustment - Exploring the Policy Issues, Workshop Proceedings, AusInfo, Canberra, 21 May.

FRG (Freehills Regulatory Group) (1999), 'National Competition Policy Review of Taxi and Hire-car Regulation', Issues Paper prepared for ACT Department of Urban Services, August.

Gabbitas, O. and D. Eldridge (1998), Directions for State Tax Reform, Productivity Commission Staff Research Paper, AusInfo, Canberra, May.

Gaunt, C. and T. Black (1994), 'The Unanticipated Effects of the Industry Commission's Recommendations on the Regulation of the Taxi Cab Industry', Economic Analysis and Policy, 24(2):151-170.

Gaunt, C. and T. Black (1996), 'The Economic Cost of Taxicab Regulation: the Case of Brisbane', Economic Analysis and Policy, 26(1):45-58. 
IC (Industry Commission) (1994), Urban Transport, Report no. 37, AGPS, Melbourne, February.

IPART (Independent Pricing and Regulatory Tribunal of New South Wales) (1999), Review of the Taxi Cab and Hire-car Industries, Interim Report no. 99-6, August.

Kenny, P. and P. McNutt (1998), 'Solving Dublin Taxi Problems, Urban-Sharecroppers v Rentseekers', Dublin Competition Authority (Discussion Paper No. 6, November).

NCC (National Competition Council) (1997), Compendium of National Competition Policy Agreements, AGPS, Canberra.

PC (Productivity Commission) (1999), Regulation of the Taxi Industry, Commission Research Paper, November.

Posner, R. (1992), Economic Analysis of Law, Fourth Edition, Little, Brown and Company, Boston.

Soon, J. (1999), 'Taxi!! Reinvigorating Competition in the Taxi Market', Policy, Winter: 13-19.

Swan, P. (1979), 'On Buying a Job: The Regulation of Taxi Cabs in Canberra', Policy Monograph 1, Centre for Independent Studies, Sydney.

TTIRG (Tasmanian Taxi Industry Review Group) (1999), Taxi Industry Act 1995 and Proposed Luxury Hire Car Legislation: Draft Regulatory Impact Statement, November.

WADT (Western Australian Department of Transport) (1999), Review of the Western Australian Taxi Industry, August.

This article draws on a Productivity Commission Research Paper 'Regulation of the Taxi Industry' published in November 1999. The author is grateful to an anonymous referee for helpful comments. 